\title{
Survey of West Yunnan Elementary Teacher Effectiveness in China
}

\author{
Qin Gao \\ Dept. Early Child Development \\ Teacher Education College \\ Qujing Normal University \\ Qujing, China
}

\begin{abstract}
This research investigated teacher variables and teaching effectiveness in west Yunnan, China. In China, everyone, every parent, grandparent, young person and citizen would like to have the assurance that all our children are being taught and prepared for college, for future work and for life. Thus, how to ensure that those who teach our children incorporate the qualities of effective teaching needs every teacher in our schools to be an effective teacher. Teacher experience, individual professional characteristics, and gender of teacher employed individual and general teaching effectiveness and descriptive research designs of survey type. The result of this survey showed us that teaching effectiveness is considered less significantly with gender but more significantly predicted work experience better than teacher professional characteristics.
\end{abstract}

Keywords-teaching effectiveness; teacher experience; teacher professional characteristics; Yunnan elementary school

\section{INTRODUCTION}

Teaching as scientific delivery process involved the systematic planning and program of instruction and experience would lead learners to acquire certain new and valuable skills, knowledge and competences both mental and physical. Therefore, it is necessary that teacher to meet academic and professional qualification in order to effective teaching and learning process. In China, everyone, every parent, grandparent, young person and citizen would like to have the assurance that all our children are being taught and prepared for college, for future work and for life. Thus, how to ensure that those who teach our children incorporate the qualities of effective teaching needs every teacher in our schools to be an effective teacher [1]. The current movement in thinking and research is taking us from the concept of a highly qualified teacher in every classroom, to the need for a highly effective teacher in every classroom [2].

Our research assumes main factors within teacher professional characteristics, teacher experience and gender of teacher which might significantly influence pupil progress. Each provides distinctive and complementary ways that teachers can understand the contribution they make. Thus, two research questions were discussed like what was the relationship between gender and teacher effectiveness? And what was the relationship among the teacher professional characteristics, teacher experience and teaching effectiveness?

\section{RELATED RESEARCH}

Adelowokan and Makinde stated teachers' experience might reflect in class control and ability to cope with needs of individual students. The length of teaching experience has been an important factor determining how effectively the teaching-learning process in a school has achieved [3]. Many researchers has examined the relationship between teaching experience and internal efficiency of schools [4] [5]. For instance, one survey in 1987 was conducted at Iraq on the analysis of socio-economic factors on students' academic achievement and found that teaching experience correlated significantly and positively with student outcome [6] [7] [8]. In 2007, one study examined the relationship between selected variables and students' achievement in Sokoto State, Nigeria in a bid to determine which of the predictor variables were statistically significant. He chose a sample of 20 schools, 700 teachers and 6 officials of the Ministry of Education at random and utilized multiple regressions to test his hypotheses [9] [10] [11]. According to his findings, teaching experience was significantly related to students' achievements. Ayodele (2005) revealed that a sizeable proportion of 64 studies that reported on the relationship between teacher degree level and student achievement found, that achievement is lower in classes where the teacher possesses an advanced degree. Contrary to this finding, some studies have shown that a positive relationship exists between teachers' qualifications and students' performance. Nyikana (1982) found that inadequate qualifications of teachers contribute to repetition in the Ciskei study [12].

\section{EXPERIMENT DESIGN}

The purpose of this study was to investigate the relationship among main factors within teacher professional characteristics, teacher experience and gender of teacher with teaching effectiveness. This study was quantitative in nature.

\section{A. Population}

The population for this study was from elementary teachers in Dali city of west Yunnan province, including 281 
female and 215 male ones. The useable return rate was $99.12 \%$.

\section{B. Reliability}

Reliability means the degree to which the research instrument is trustworthy. The most preferred reliability test of the questionnaire is Cronbach $\alpha$. Higher Cronbach $\alpha$ means higher internal consistency. The Cronbach $\alpha$ of original questionnaire in different sections of questionnaire (teaching professional skills, teaching experience and gender) were $.85, .86$ and .84 . From viewing the total score of the Cronbach $\alpha$, the reliability was all above .70 ( $\alpha>$.70), which meant that this questionnaire could become a reliable instrument to test the population "Table I".

\section{TABLE I. COEFFICIENTS OF TEACHING EFFECTIVENESS}

\begin{tabular}{|l|l|l|}
\hline \multicolumn{1}{|c|}{ Reliability of factors } & Number of questions & Cronbach's alpha \\
\hline Professional Characteristics & 15 & .85 \\
\hline Experience & 15 & .86 \\
\hline Gender & 4 & .84 \\
\hline
\end{tabular}

\section{Content Validity}

The teaching effectiveness questionnaire is designed to sample opinions of former studies to reflect upon the various aspects of teacher characteristics. The questionnaire is meant to supplement, rather than replace, and the collected data may be used to evaluate curricula and teachers on an individual professorial level and on a regional teachers to enhance the content validity in the current study, all questionnaires were examined and translated from Chinese into English.

\section{Procedure}

The scope of the sampling was directed to teaching effectiveness in west Yunnan. The survey started by obtaining help from several faculty who were associated with couples of elementary schools in Dali city of Yunnan province. Survey participants received a memo of introduction and were informed consent letter was obtained through the completion of the survey. 500 survey questionnaires were distributed from January to February 2016. 496 were returned for a returned rate $99.12 \%$. All the participants were chosen by convenience in at elementary schools in Dali city.

\section{DATA ANALYIS}

The purpose of this study was to investigate the relationship among main factors within teacher professional characteristics, teacher experience and gender of teacher with teaching effectiveness. This study was quantitative in nature. According to the research questions, the results of this study were divided into the following: A. demographic characteristics of respondents, B. descriptive statistics of each factor in teaching effectiveness variables, C. descriptive statistics of each approach in teaching effectiveness variables.

\section{A. Demographic Characteristics of Respondents}

The basic information of participants was described in "Table II". According to all useable questionnaires, 56.7\% were female. In professional characteristics status, high school degree ones were $4.2 \%$, normal high school degree ones were $22.6 \%$, normal college degree ones were $63.1 \%$. In experience, $9.5 \%$ were less than 5 years, $21 \%$ were $6-10$ years, $19.9 \%$ were $11-15$ years, $20.1 \%$ were $16-20$ years, $16.9 \%$ were $21-25$ years, and more than 26 years were $12.6 \%$. $23 \%$ participating schools were located in urban area.

TABLE II. FREQUENCY AND PERCENTAGE OF VARIABLES

\begin{tabular}{|l|l|l|l|}
\hline \multicolumn{1}{|c|}{ Variables } & \multicolumn{1}{|c|}{ Description } & Number & Percentage \\
\hline Gender & Male & 215 & $43.3 \%$ \\
\hline & Female & 281 & $56.7 \%$ \\
\hline Professional Characteristics & Primary School & 2 & $4 \%$ \\
\hline & High School & 21 & $4.2 \%$ \\
\hline & Normal High School & 112 & $22.6 \%$ \\
\hline & Normal College & 313 & $63.1 \%$ \\
\hline & Undergraduate and & 48 & $6.1 \%$ \\
& Graduate & & \\
\hline & Less 5 years & 47 & $9.5 \%$ \\
\hline & $6-10$ years & 104 & $21 \%$ \\
\hline & $11-15$ years & 99 & $19.9 \%$ \\
\hline & $16-20$ years & 100 & $20.1 \%$ \\
\hline & $21-25$ years & 84 & $16.9 \%$ \\
\hline Elementary School Zone & More 26 years & 62 & $12.6 \%$ \\
\hline & Urban Area & 115 & $23 \%$ \\
\hline & Rural Area & 381 & $77 \%$ \\
\hline
\end{tabular}

\section{B. Descriptive Statistics of Each Factor}

The basic information of participants was described in "Table II". In "Table III", the male teachers was 5.0238 on individual teaching effectiveness $(\mathrm{SD}=0.54527)$, the female teachers was 5.0331 on individual teaching effectiveness $(\mathrm{SD}=0.54049)$; the male teachers was 4.5819 on general teaching effectiveness $(\mathrm{SD}=0.77905)$, the female teachers was 4.4900 on general teaching effectiveness $(\mathrm{SD}=$ $0.74429)$; the male teachers was 4.8601 on teaching effectiveness ( $\mathrm{SD}=0.52086$ ), the female teachers was 4.8319 on teaching effectiveness $(\mathrm{SD}=0.48309)$. To more accurately describe gender in teaching effectiveness of participants, it was indicated that $\mathrm{T}$-value was $0.189,1.334$, 0.622 respectively $(p>.05)$, and was not significant across gender. Therefore, there was no relationship between teacher effectiveness and gender.

TABLE III. MEAN AND STANDARD DEVIATION By GENDER

\begin{tabular}{|l|c|c|c|c|c|}
\hline & \multicolumn{2}{|c|}{ Male } & \multicolumn{2}{c|}{ Female } & $\begin{array}{c}\text { T- } \\
\text { Value }\end{array}$ \\
\hline & $\boldsymbol{M}$ & $\boldsymbol{S D}$ & $\boldsymbol{M}$ & $\boldsymbol{S D}$ & \\
\hline $\begin{array}{l}\text { Individual Teaching } \\
\text { Effectiveness }\end{array}$ & 5.0238 & .54527 & 5.0331 & .54049 & .189 \\
\hline $\begin{array}{l}\text { General Teaching } \\
\text { Effectiveness }\end{array}$ & 4.5819 & .77905 & 4.4900 & .74429 & 1.334 \\
\hline $\begin{array}{l}\text { Teaching } \\
\text { Effectiveness }\end{array}$ & 4.8601 & .52086 & 4.8319 & .48309 & .622 \\
\hline
\end{tabular}




\section{Descriptive Each Approach in Teaching Effectiveness Variable}

In "Table IV", the teachers with primary school degree was 4.1765 on individual teaching effectiveness $(\mathrm{SD}=$ 0.16638 ), was 3.7500 on general teaching effectiveness (SD $=0.49497$ ), was 4.0185 on teaching effectiveness (SD $=0.28808$ ); the teachers with high school degree was 4.9580 on individual teaching effectiveness $(\mathrm{SD}=0.62562)$, was 3.7500 on general teaching effectiveness $(\mathrm{SD}=0.79600)$, was 4.7690 on teaching effectiveness $(\mathrm{SD}=0.52141$ ); the teachers with normal high school degree was 5.1077 on individual teaching effectiveness ( $\mathrm{SD}=0.53319$ ), was 4.5643 on general teaching effectiveness $(\mathrm{SD}=0.79524)$, was 4.9064 on teaching effectiveness ( $\mathrm{SD}=0.48784$ ); the teachers with normal college degree was 5.0105 on individual teaching effectiveness $(\mathrm{SD}=0.52832$ ), was 4.5300 on general teaching effectiveness (SD $=0.74987$ ), was 4.8326 on teaching effectiveness ( $\mathrm{SD}=0.49289$ ); the teachers with undergraduate and graduate school degree was 5.0331 on individual teaching effectiveness $(\mathrm{SD}=0.59383)$, was 4.5167 on general teaching effectiveness $(\mathrm{SD}=0.74329)$, was 4.8418 on teaching effectiveness ( $\mathrm{SD}=0.54195)$; there was no difference among primary school degree, high school degree, normal high school degree, normal college degree, and undergraduate or graduate degree on individual teaching, general teaching or teaching effectiveness.

TABLE IV. MEAN AND Standard DEVIATION By PROFESSIONAL CHARACTERISTICS

\begin{tabular}{|c|c|c|c|c|}
\hline & & $\begin{array}{c}\text { Individual } \\
\text { Teaching } \\
\text { Effectiveness }\end{array}$ & $\begin{array}{c}\text { General } \\
\text { Teaching } \\
\text { Effectiveness }\end{array}$ & $\begin{array}{c}\text { Teaching } \\
\text { Effectiveness }\end{array}$ \\
\hline \multirow{2}{*}{$\begin{array}{c}\text { Primary } \\
\text { School }\end{array}$} & $M$ & 4.1765 & 3.7500 & 4.0185 \\
\hline & $S D$ & .16638 & .49497 & .28808 \\
\hline \multirow[t]{2}{*}{ High School } & $M$ & 4.9580 & 4.4476 & 4.7690 \\
\hline & $S D$ & .62562 & .79600 & .52141 \\
\hline \multirow{2}{*}{$\begin{array}{c}\text { Normal High } \\
\text { School } \\
\end{array}$} & $M$ & 5.1077 & 4.5643 & 4.9064 \\
\hline & $S D$ & .53319 & .79524 & .48784 \\
\hline \multirow{2}{*}{$\begin{array}{l}\text { Normal } \\
\text { College }\end{array}$} & $M$ & 5.0105 & 4.5300 & 4.8326 \\
\hline & $S D$ & .52832 & .74987 & .49289 \\
\hline \multirow{2}{*}{$\begin{array}{l}\text { Undergraduate } \\
\text { and Graduate }\end{array}$} & $M$ & 5.0331 & 4.5167 & 4.8418 \\
\hline & $S D$ & .59383 & .74329 & .54195 \\
\hline \multicolumn{2}{|l|}{$\mathbf{F}$} & 2.025 & .647 & 1.978 \\
\hline
\end{tabular}

In "Table V", the teacher experience with less than 5 years was 4.8498 on individual teaching effectiveness (SD = 0.49926 ), was 4.6660 on general teaching effectiveness (SD $=0.70349$ ) , was 4.7817 on teaching effectiveness (SD $=0.42659)$; the teacher experience with 6-10 years was 4.8925 on individual teaching effectiveness $(\mathrm{SD}=0.52418)$, was 4.4577 on general teaching effectiveness (SD $=0.64668$ ), was 4.7315 on teaching effectiveness (SD $=0.43834)$; the teacher experience with 11-15 years was 5.0428 on individual teaching effectiveness $(\mathrm{SD}=0.54316)$, was 4.4365 on general teaching effectiveness $(\mathrm{SD}=0.84604$ ) was 4.9064 on teaching effectiveness $(\mathrm{SD}=0.48784)$; the teachers with normal college degree was 5.0105 on individual teaching effectiveness $(\mathrm{SD}=0.52832)$, was 4.7849 on general teaching effectiveness $(S D=0.54576)$, was 4.8326 on teaching effectiveness ( $\mathrm{SD}=0.49289$ ); the teacher experience with $16-20$ years was 5.0682 on individual teaching effectiveness ( $\mathrm{SD}=0.54337$ ), was 4.6240 on general teaching effectiveness ( $\mathrm{SD}=0.71846$ ), was 4.9037 on teaching effectiveness ( $\mathrm{SD}=0.50267$ ); the teacher experience with 21-25 years was 5.1681 on individual teaching effectiveness $(\mathrm{SD}=0.48954)$, was 4.6702 on general teaching effectiveness ( $S D=0.78798)$, was 4.9837 on teaching effectiveness ( $\mathrm{SD}=0.46913$ ); the teacher experience more than 26 years was 5.1205 on individual teaching effectiveness $(\mathrm{SD}=0.60275)$, was 4.4984 on general teaching effectiveness $(\mathrm{SD}=0.81028)$, was 4.8901 on teaching effectiveness $(\mathrm{SD}=0.55650)$; there was significant difference among teacher experience on individual teaching, general teaching or teaching effectiveness.

TABLE V. MEAN AND STANDARD DEVIATION By EXPERIENCE

\begin{tabular}{|c|c|c|c|c|}
\hline & & $\begin{array}{c}\text { Individual } \\
\text { Teaching } \\
\text { Effectiveness }\end{array}$ & $\begin{array}{c}\text { General } \\
\text { Teaching } \\
\text { Effectiveness }\end{array}$ & $\begin{array}{c}\text { Teaching } \\
\text { Effectiveness }\end{array}$ \\
\hline \multirow{2}{*}{$\begin{array}{l}\text { Less } 5 \\
\text { years }\end{array}$} & $M$ & 4.8498 & 4.6660 & 4.7817 \\
\hline & $S D$ & .49926 & .70349 & .42659 \\
\hline \multirow{2}{*}{$\begin{array}{c}6-10 \\
\text { years }\end{array}$} & $M$ & 4.8925 & 4.4577 & 4.7315 \\
\hline & $S D$ & .52418 & .64668 & .43834 \\
\hline \multirow{2}{*}{$\begin{array}{l}\text { 11-15 } \\
\text { years }\end{array}$} & $M$ & 5.0428 & 4.4365 & 4.7849 \\
\hline & $S D$ & .54316 & .84604 & .54576 \\
\hline \multirow{2}{*}{$\begin{array}{l}16-20 \\
\text { years }\end{array}$} & $M$ & 5.0682 & 4.6240 & 4.9037 \\
\hline & $S D$ & .54337 & .71846 & .50267 \\
\hline \multirow{2}{*}{$\begin{array}{l}21-25 \\
\text { years }\end{array}$} & $M$ & 5.1681 & 4.6702 & 4.9837 \\
\hline & $S D$ & .48954 & .78798 & .46913 \\
\hline \multirow{2}{*}{$\begin{array}{c}\text { More } 26 \\
\text { years }\end{array}$} & $M$ & 5.1205 & 4.4984 & 4.8901 \\
\hline & $S D$ & .60275 & .81028 & .55650 \\
\hline \multicolumn{2}{|l|}{$\mathbf{F}$} & $.043 *$ & $.037 *$ & $.027 *$ \\
\hline
\end{tabular}

\section{Result}

What was the relationship between gender and teacher effectiveness? In this study, the value of T was $0.189,1.334$, 0.622 respectively which was no significance, then teaching effectiveness is considered less significantly with gender.

What was the relationship among the teacher professional characteristics, teacher experience and teaching effectiveness?

The $F$ test is used to test the significance of teacher professional characteristics, teacher experience. If prob $(F)$ $<.05$, then this is considered significantly better than would be expected by chance. Therefore, teacher experience, in this question, is significantly predicted work experience better than teacher professional characteristics.

\section{CONCLUSION}

Parents, practitioners, and policymakers agree that the key to improving primary education in China is placing highly skilled and effective teachers in all classrooms. Yet the nation still lacks a practical set of standards and assessments that can guarantee that teachers, particularly new teachers, are well prepared and ready to teach[13] [14] [15]. This survey discusses a promising approach to the question of how to measure teacher effectiveness. Specifically, it describes the ways in which assessments of teacher performance for professional characteristics cannot 
reflect and predict teachers' success. It outlines progress in the field of teacher assessment development and discusses policies that could create much greater leverage on the quality of teacher preparation and teaching than has previously existed in China. One important lesson from these efforts is the repeated finding that teachers are the fulcrum determining whether any school initiative tips toward success or failure. Every aspect of school reform depends on highly skilled teachers for its success. This is especially true as educational standards rise and the diversity of the student body increases.

\section{ACKNOWLEDGMENT}

This research is support by Yunnan Province Social Science Grant.

\section{REFERENCES}

[1] Adelowokan, P.A. and Makinde, F.B. (2011).Attitude of teachers towards gifted children in secondary schools in Nigeria. In Ikere Journal of Education, Ikere-Ekiti Vol. 13 pp 21-28.

[2] Adeyemi, T. O.(1998). School and teacher variables associated with the performance of students in the seniorsecondary certificate examinations in Ondo state Nigeria. Ph.D Thesis (Unpublished). University of Hull,United Kingdom.

[3] Colton A B,Spark-LangerG M. A conceptual frame work to guide the development of teacher reflection and decision making[J]. Journal of Teacher Education, 1993,44(1).

[4] Huberman M,Grounauer M,Marti J. The life of teachers[M]. translated by Neufeld J. London: Cassell villiershouse; New York: Teacher College press, 1993.

[5] Guskey T R, Passaro P D. Teacher-efficacy: A study of construct dimensions [J]. American Educational ResearchJournal, 1994, (4): 627-643.

[6] Ajayi, I. D. (1999). Analysis of teachers' job performance and secondary school students academic achievement and their relationships. African journal of educational research. Vol. 5 No 2. Pp 85-90.

[7] Aladejana, F.O. and Odejobi C.O. (2006). Actualizing the Effective Learning of Science in a Globalized World:The Place of the Nigerian Indigenous Science, Conference Proceedings. International Conference for School Effectiveness and Improvement, Florida, USA.

[8] Ambasht, N.K. (2003). Teacher Education in the newMillennium Challenges and Strategies. In Teacher Education in Nigeria: Past, Present and Future, Kaduna, National Teachers' Institute.

[9] Ayodele, J.B. (2005). Fundamentals of systems analysis in education. Lagos, Bolabay Publications.

[10] Awoyemi, V O. (2012), Relationship between teacher characteristics and student performance in kwarastate, Nigeria. Unpublished M.Ed These, University of Binin, Binin City, Nigeria.

[11] Coleman, J. S, Hoffer, T \& Kilgore, S (1981). Relationship between students' performance and teacher effectiveness, Chicago. National Open Research Center.

[12] Nyikana, H.K. (1982). Pupil repetition in the primary schools of Ciskei Unpublished Master's Thesis, Universityof Orange Free State.

[13] Reuks Steven F (1992): Characteristics of successful schools. Perception of difference between rural and urban elementary school teachers (ED 360113) in ERIC educational research centre.

[14] Williams T. D. (1965). Wastage rates and teacher quality in Guatemalan schools. In comparative education review 9, 46-52.

[15] Abbott, M. Conversations about teaching. Marylhurst University, 2009 . 